\title{
Hand Contamination among Food Handlers: A Study on the Assessment of Food Handlers in Canteen of Various Hospitals in Solapur City, Maharashtra
}

\author{
Anu Sharma ${ }^{1 *}$ (D) , Subarnolata Gangopadhyay² ${ }^{\mathbb{D}}$, Jugal Kishor Agarwal ${ }^{1}$ (D), \\ Amit Kumar ${ }^{1}$ and K.V. Ingole ${ }^{2}$ \\ ${ }^{1}$ Department of Microbiology, Rama Medical College Hospital and Research Center, Hapur- 245 304, Uttar \\ Pradesh, India. \\ ${ }^{2}$ Dr. V.M. Govt. Medical College Solapur - 413 736, Maharashtra, India.
}

\begin{abstract}
Food handlers often act as an important vehicle for the transmission of microorganisms responsible for causing foodborne illness, which pose as a major public health problem of global concern. Poor hygiene while preparation of food is a major source of illness caused by pathogenic microbes. This study was done for a period of $\mathbf{2}$ months after approval from the Institutional Ethical Committee. The study population included food handlers working in canteens of various hospitals in Solapur. Swabs from hands, nose and fingernail specimens were collected and inoculated on bacteriological culture media and identification was done using standard protocols. Data was collected using a structured questionnaire to evaluate the socio-demographic status and self-hygiene practices followed by the food handlers. Data were analyzed using an appropriate statistical test. All the people involved in food handling including the cook, server and cleaner were included after a written informed consent. The sample size was $\mathbf{4 5}$ food handlers. From the $\mathbf{4 5}$ food handlers which were included in the study there were 20 cooks (44.44\%), 14 servers (31.11\%) and 11 cleaners $(24.45 \%)$ Out of these 45 food handlers $22(49 \%)$ were males and $23(51 \%)$ were females. Knowledge about basic health education was seen in $73.33 \%$ of the subjects, while only $18 \%$ were sensitized to hand washing, $22.22 \%$ had annual health examination, $35.5 \%$ wore finger ornaments. Of 45 food handlers $69 \%$ had trimmed fingernails, $73.3 \%$ washed their hands regularly. However, no association was found between these factors and hand contamination. This may be because none of the food handlers used soap or hand sanitizer to clean their hands. They used plain water to wash their hands. Food handlers act as an important source in transmission of foodborne illnesses therefore it is necessary to sensitize and create awareness amongst them about the importance of hand hygiene.
\end{abstract}

Keywords. Hand hygiene, food handlers, annual health examination, food borne illness

*Correspondence: dranusharma2014@gmail.com; +91 7721091299

(Received:May 26, 2021; accepted: July 28, 2021)

Citation: Sharma A, Gangopadhyay S, Agarwal JK, Kumar A, Ingole KV. Hand Contamination among Food Handlers: A Study on the Assessment of Food Handlers in Canteen of Various Hospitals in Solapur City, Maharashtra. J Pure Appl Microbiol. 2021; 15(3):1536-1546. doi: 10.22207/JPAM.15.3.48

(C) The Author(s) 2021. Open Access. This article is distributed under the terms of the Creative Commons Attribution 4.0 International License which permits unrestricted use, sharing, distribution, and reproduction in any medium, provided you give appropriate credit to the original author(s) and the source, provide a link to the Creative Commons license, and indicate if changes were made. 


\section{INTRODUCTION}

Food handlers act as an important source for dissemination of food borne illness and pose as a threat to the public health. Over the years due to high morbidity and mortality due to diarrheal diseases food borne illness have become public health problem of global concern ${ }^{1}$. According to WHO the statistics as on $30^{\text {th }}$ April 2020 it is estimated that almost 1 in every 10 people fall sick due to intake of contaminated food items and 420,000 die every year due to food borne illness. Diarrheal diseases attribute to about 600 million people getting sick and about 420,000 deaths annually, which results in the loss of 33 million healthy daily life years (DALYS) ${ }^{2}$.

In India the extent of the problem remains unclear due to fewer studies which include parameters like hand hygiene and awareness on food borne illness among food handlers. Often due to scarcity of resources outbreaks of food borne illness either go unreported or uninvestigated until the magnitude of problem is big in terms of health or monetary damage. It is important that steps should be taken to prevent future outbreaks by strengthening policies on food safety which are yet to be established ${ }^{3}$.

WHO defined food handlers as those persons who in the course of their normal routine work, handle food or food items or those who may come into contact with handling of eating and drinking utensils not meant for their personal use ${ }^{4}$. Food contamination can occur by varied sources however food handlers often act as carriers of such infections due to lack of awareness about hand hygiene practices ${ }^{5}$. Poor hygiene while preparation of food could be potential source of infection due to pathogenic bacteria ${ }^{6,7}$. Food handlers can contaminate the food by spreading bacteria on the surfaces that food will come in contact example- work tops, food packaging before it is used, food handlers can also contaminate other surfaces such as door handles that enable transmission of bacteria to other food handler's hand who are involved in food preparation and serving ${ }^{8}$. Food handlers often transmit infection as they may carry these microbes as their skin flora, or may be present in their nasal secretions or stool $^{9}$. As per CDC food handlers attribute to about $20 \%$ of food borne illness. For better tracking and investigation of food borne illnesses and outbreaks
CDC has put forward surveillance systems like Pulsenet, Foodnet and the system for enteric disease response, investigation and coordination $(\text { SEDRIC })^{10}$.

Hand hygiene is most important step to limit food borne illness. As often due to lack of hand hygiene hands of food handlers aid in food contamination. As hands are used right from cleaning food items to preparation and storage, thus unclean hands harbor pathogenic microbes which results in food borne illness. It is important to sensitize individuals handling food items about hand hygiene i.e. how to wash hands, when to wash hands and the duration of hand washing. Therefore until and unless such corrective measures are not followed properly it will be difficult to contain such episodes of food borne illness ${ }^{12,13}$.

Food borne illness can be infectious or toxic in nature, caused by consumption of food. Food borne illness has been associated with 40 different kinds of bacteria, viruses, parasites and moulds ${ }^{14}$. Contaminated food may not look, taste or smell any different from food that is safe to eat. Most common symptoms of food borne illness include diarrhea and vomiting ${ }^{15}$.

Staphylococcus aureus is a common colonizer in hands. Organisms like Staphylococcus aureus and Escherichia coli which are commonly associated with food borne illness can survive for days on the surfaces and unclean hands often result in episodes of diarrheal disease ${ }^{16}$. These microbes have been associated with food borne illnesses and have been associated with increase in mortality and morbidity among patients along with hospital stay and increase financial burden on the patients ${ }^{17}$.

Food handlers in bigger eating establishment like hospital canteens, cater to large number of people including doctors, paramedical staff and patients attendants, these food handlers therefore are more important epidemiologically as compared to domestic food handlers in spreading food borne illnesses ${ }^{1}$. The cleanliness and personal hygiene of workers or food handler that handle food directly or indirectly must be managed to minimize the risk of contamination ${ }^{18}$. The availability of restroom and hand washing basins are important in preventing contamination of food produced by food handlers ${ }^{19}$. 
Food handlers are the individuals who are involved in food handling involving food preparation as well as serving of food ${ }^{20}$. WHO emphasizes that "outbreak of food borne diseases" can be decreased by adhering to self -hygiene practices among food handlers ${ }^{21}$. Various studies have shown that number of outbreaks of bacterial and viral infections and role of food handlers in causing food borne illness among individuals due to their poor sanitary practices and negligence in practices like regular hand washing ${ }^{22,23}$. Fecaloral transmission is common mode of infection transmission that results in food borne illness. Food, water, nails, hands all can act as a vector for transmission of such infections ${ }^{24}$. In absence of proper hand hygiene nail bed may act as an important source of harboring pathogenic bacteria ${ }^{25}$. Individuals involved in preparation of food should avoid smoking, coughing, eating or handling money while food preparation as these practices may result in cross contamination ${ }^{26}$. Hand washing is the most important step to prevent spread of food borne illness ${ }^{26,27}$.

Therefore present study has been undertaken with the aim to evaluate bacterial micro flora among food handlers with assessment of bacterial contamination on hands and anterior nares of food handlers which act as an important vehicle in transmission of infection to the food consumers, in our case food is consumed by doctors, paramedical staff, interns, students and attendants of patients admitted to the hospital. Therefore this study will help in tracking carriers and infected food handlers and help in increasing awareness among food handlers on importance of hand washing in prevention of spread of infection to others.

\section{Aim and Objective}

1. To evaluate hand hygiene among food handlers working in canteens across various hospitals in Solapur city, Maharashtra.

2. To evaluate the need of sensitization about hand hygiene among food handlers working in canteens of various hospitals in Solapur city, Maharashtra.

\section{MATERIAL AND METHOD}

The study was conducted among food handlers working in canteens of major hospitals in Solapur city, Maharashtra. The study was performed for a period of 2 months. All the people involved in food handling including the cook, server and cleaner were included after a written informed consent. The sample size is 45 food handlers.

\section{Type of study- Cross sectional study}

Source population- Those individuals concerned with food handling who work in canteen across major hospitals in Solapur were included.

\section{Selection criteria \\ Inclusion criteria}

All individuals who handle food including those involved in preparation, storage and cleaning not meant for their personal use ${ }^{4}$ working in canteens of various hospitals in Solapur, Maharashtra. Food handlers should not be suffering from skin inflammation, eczema or irritation.

\section{Exclusion criteria}

Food handlers with any skin disease/ inflammation/eczema or irritation were excluded. Sample size- All food handlers working in canteens including cook, server and cleaner in major hospitals in Solapur were included in the study.

The total number of subjects were 45 food handlers.

Before the study was conducted permission from the institutional ethics committee was taken. Permission from other hospitals to conduct study on their food handlers was also taken. Written consent was taken from all the participants included in the study.

A structured questionnaire was used to record hygiene practices, level of education and socio demographic status of the food handlers. All the data collected from the individuals was confidential and not disclosed.

Questionnaire for Assessment of Hand Hygiene Name: Age: Sex: Work in canteen:

1. Have suffered from diarrhea or vomiting over the last 7 days?

Yes $\mathrm{CNo}$

2. Do you now, or have you ever suffered from:

a) Eczema, dermatitis or any other skin condition affecting hands, arms or face? Yes $\square$ No $\square$ b) Boils, styes or septic fingers? Yes $\quad$ No $\square$

c) Discharge or infection of the eyes, ears, gums or mouth? Yes $\mathrm{CNo} \square$

3. Do you suffer from recurring diarrhea, vomiting 
or a bowel disorder?

Yes $\square$ No $\square$

4. Do you know the correct method to wash hands? Yes $\square$ No $\square$

5. Do you wash their hands regularly? Yes $\square$ No $\square$

6. Do you have short nails? Yes $\square$ No $\square$ 7. Do you use hair protection? Yes $\square$ No $\square$ 8. Do you touch food with your hands without washing? Yes $\square$ No $\square$ 9. Do you wear finger ornaments? Yes $\square$ No $\square$ 10. Do you have wounds or infectionson their hands Yes $\square$ No $\square$

11. Do you go for Annual health examinations? Yes $\square$ No $\square$

12. Do you use soap while washing hands? Yes $\square$ No $\square$

The association between various risk factors and contamination was found using Chi square test and Fischer exact test.

\section{Procedure}

Sterile swabs were used to collect samples from hand, nose and bed of fingernails. Before taking samples the swabs we moistened using sterile saline. This swab was then used to collect sample of each patient. The sample was immediately transferred to a sterile test tube and transported to Microbiology laboratory. The samples were inoculated on blood agar and Mac Conkey agar and nutrient agar and plates were transferred to the incubator for incubation for 18-24 hours. The plates were examined for growth after appropriate incubation. Bacteriological identification was done as per standard protocol ${ }^{32}$. Smears of growth were made and stained with using gram stain. On the basis of culture characteristics, smear microscopy, biochemical tests were performed. In case of gram positive cocci catalase, oxidase, coagulase- slide and tube, mannitol fermentation and bile esculin was used. While in case of Gram negative bacteria indole, Methyl red, Voges- Proskauer, Citrate tests were used for classification. Appropriate ATCC controls were used for identification of organisms. Escherichia coli ATCC 25922, Staphylococcus aureus ATCC 25923.

The data was collected and analyses using Microsoft Excel 2010. The association between various risk factors and contamination was found using Chi square test and Fischer exact test. handlers were taught the right method of washing their hands. They were educated about the benefits of hand washing and about the harms of not washing their hands properly. They were also educated about the kind of diseases that would spread if hand washing was not practiced.

\section{RESULT}

In the present study, samples were collected from 45 food handlers which included 20 cooks (44.44\%), 14 servers (31.11\%) and 11 cleaners (24.45\%). As shown in Table-1.

The age group of the food handlers ranged from 18 to 75 years with mean age of 39.8 years. As shown in Table-2.

Among 45 food handlers 12 (27\%) were illiterate and $33(73 \%)$ were literate. As shown in Table-3.

Out of 45 food handlers only 10 (22.22\%) had annual health examination and only $8(18 \%)$ were already sensitized for hand hygiene. As shown in Table-4 and Table-5.

All the food handlers were using only water and no soap to wash their hands while doing their chores.

Out of 45 food handlers 31 (69\%) had short nails, $2(4.44 \%)$ of the food handlers were using hair protection, $16(35.5 \%)$ food handlers were wearing finger ornaments and $2(4.44 \%)$ of the food handlers had recent history of diarrhea and vomiting for which they were already treated. None of them had any wound or skin infection. As shown in Table- 6 and Fig-1.

From a total of 45 food handlers, 65 bacterial isolates were obtained. Out of which $41(63.07 \%)$ were obtained from hands of food handlers while $24(37 \%)$ were obtained from anterior nares of the food handlers.

Table 1. Distribution of food handlers included in the study

\begin{tabular}{lccc}
\hline No. & Work in canteen & Number & Percentage \\
\hline 1. & Cook & 20 & $44.44 \%$ \\
2. & Server & 14 & $31.11 \%$ \\
3. & Cleaner & 11 & $24.45 \%$ \\
4. & TOTAL & 45 & $100 \%$
\end{tabular}

Out of the total 45 food handlers 22 (49\%) were males and $23(51 \%)$ were females.

After collection of sample the food 
Majority of bacterial isolates obtained from the hand and anterior nares were gram positive bacteria.

In the hands of the food handlers most common organism isolated were Bacillus species 18 (44\%) followed by Staphylococcus aureus 10 (25\%), Citrobacter species 6 (14.63\%), CONS (Cogulase negative Staphylococcus) 3 (7.31\%), Proteus species 2 (5\%), E. coli 1 (2.43\%) and Enterococcus species 1 (2.43\%) Fig-2.

Table 2. Distribution of food handlers on the basis of age group

\begin{tabular}{lcc}
\hline No. & Age group & Number \\
\hline 1 & $18-20$ & 3 \\
2 & $21-30$ & 8 \\
3 & $31-40$ & 13 \\
4 & $41-50$ & 15 \\
5 & $51-60$ & 5 \\
6 & $61-70$ & 0 \\
7 & $>75$ & 1 \\
\hline
\end{tabular}

Table 4. Annual health examination data among food handlers

\begin{tabular}{lccc}
\hline No. & $\begin{array}{c}\text { Annual Health } \\
\text { Examination }\end{array}$ & Number & Percentage \\
\hline 1 & Yes & 10 & $22.22 \%$ \\
2 & No & 35 & $77.78 \%$ \\
\hline
\end{tabular}

Bacterial isolates from anterior nares of the food handlers showed majority of bacterial isolates of Staphylococcus aureus 12(50\%) followed by Bacillus species 6(25\%), Diphtheroids 5 (21\%) and CONS 1 (4\%). As shown in Fig-3.

Overall bacterial isolates obtained from hands and anterior nares of food handlers were Staphylococcus aureus 34\% followed by Bacillus species 24.6\%, Diphtheroids 20\%, Citrobacter species 9\%, CONS 6\%, Proteus species 3.3\% E. coli $1.5 \%$, Enterobacter species 1.5\%. As shown in Fig-4.

The association between hand

Table 3. Distribution of food handlers on the basis of literacy level

\begin{tabular}{lcc}
\hline No. & Education & Number \\
\hline 1 & No formal education & 12 \\
2 & Primary & 10 \\
3 & Secondary & 19 \\
4 & Graduate & 4 \\
\hline
\end{tabular}

Table 5. Food handlers sensitized for hand hygiene

\begin{tabular}{lccc}
\hline No. & $\begin{array}{c}\text { Sensitized to } \\
\text { hand hygiene }\end{array}$ & Number & Percentage \\
\hline 1 & Yes & 8 & $18 \%$ \\
2 & No & 37 & $82 \%$ \\
\hline
\end{tabular}

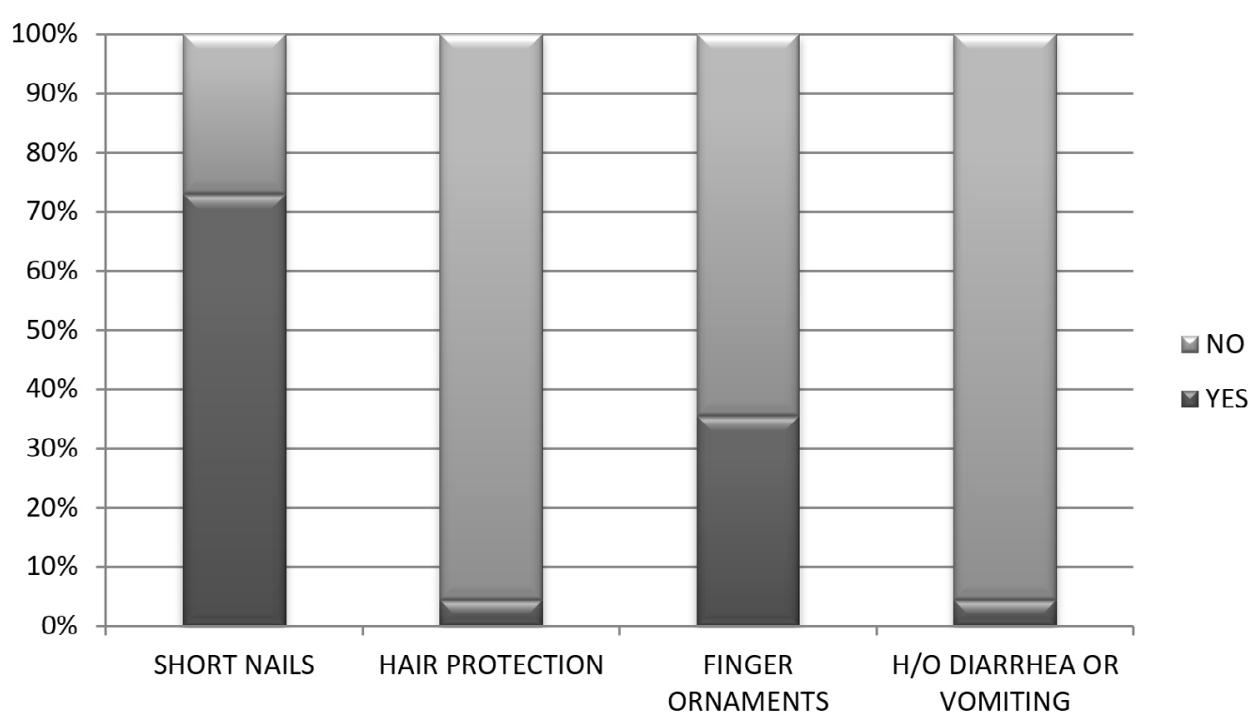

Fig. 1. Different parameters of self-hygiene practices among food handlers 
contamination and various risk factors were found using Chi square test and Fisher Exact test. The results were as follows (as shown in Table-7).

\section{DISCUSSION}

Food handlers can act as an important source for spreading food borne illness. Proper implementation of self-hygiene practices, importance of hand washing, general health
Table 6. Self hygiene practices among food handlers

\begin{tabular}{lcrrr}
\hline No. & $\begin{array}{c}\text { Miscellaneous } \\
\text { findings }\end{array}$ & Yes & No & Total \\
\hline 1 & Short nails & 31 & 14 & 45 \\
2 & Hair protection & 2 & 43 & 45 \\
3 & Finger ornaments & 16 & 29 & 45 \\
4 & h/o diarrhea or & 2 & 43 & 45 \\
& vomiting & & & \\
\hline
\end{tabular}

\title{
BACTERIAL ISOLATES OF HAND
}

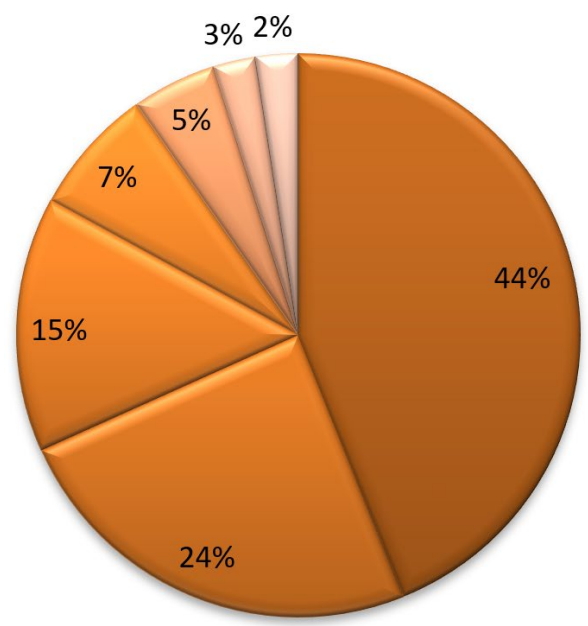

$\square$ Bacillus species

Staphylococcus aureus

$\square$ Citrobacter species

$\square$ CONS

$\square$ Proteus species

$\square$ E. coli

$\square$ Enterococcus species

Fig. 2. Distribution of bacterial isolates from hands of food handlers

\section{BACTERIAL ISOLATES OF ANTERIOR NARES}

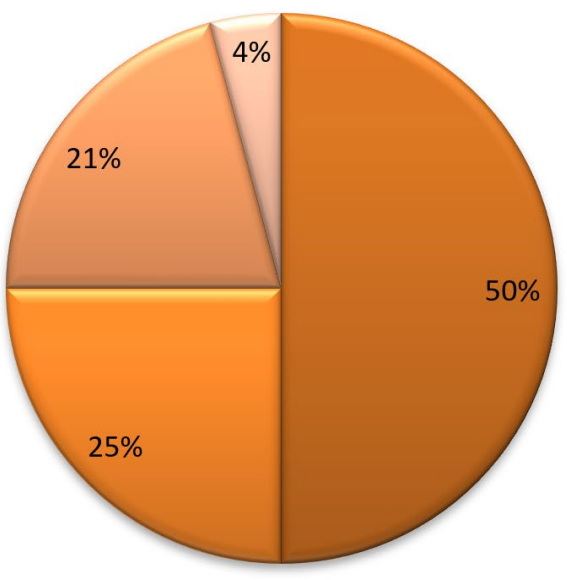

\author{
$\square$ Staphylococcus aureus \\ $\square$ Bacillus species \\ $\square$ Diphtheroids \\ $\triangle$ CONS
}

Fig. 3. Distribution of bacterial isolates from anterior nares of food handlers 
Table 7. The association between hand contamination and various risk factors found using Chi square test and Fisher Exact test

\begin{tabular}{|c|c|c|c|}
\hline \multirow[t]{2}{*}{ Risk Factors } & \multicolumn{2}{|c|}{ Hand Contamination } & \multirow[t]{2}{*}{$p$-Value } \\
\hline & Present & Absent & \\
\hline \multicolumn{4}{|l|}{ GENDER } \\
\hline Male & 13 & 9 & 0.463 \\
\hline Female & 16 & 7 & \\
\hline \multicolumn{4}{|l|}{ EDUCATION } \\
\hline$<=4^{\text {th }}$ grade & 11 & 6 & 0.616 \\
\hline$>=4^{\text {th }}$ grade & 16 & 12 & \\
\hline \multicolumn{4}{|c|}{ INFORMAL HAND HYGIENE } \\
\hline \multicolumn{4}{|l|}{ TRAINING } \\
\hline Yes & 6 & 2 & 0.69 \\
\hline No & 22 & 15 & \\
\hline \multicolumn{4}{|c|}{ REGULAR HAND WASHING } \\
\hline Yes & 21 & 12 & 0.746 \\
\hline No & 7 & 5 & \\
\hline \multicolumn{4}{|c|}{ TRIMMED FINGER NAILS } \\
\hline Yes & 20 & 13 & 0.49 \\
\hline No & 9 & 3 & \\
\hline \multicolumn{4}{|c|}{ FINGER ORNAMENTS } \\
\hline Yes & 11 & 5 & 0.502 \\
\hline No & 17 & 12 & \\
\hline \multicolumn{4}{|c|}{ USE OF HAIR TIE } \\
\hline Yes & 1 & 1 & 1 \\
\hline No & 16 & 12 & \\
\hline \multicolumn{4}{|c|}{ JOB POSITION } \\
\hline Cook & 12 & 8 & 0.92 \\
\hline Server & 9 & 5 & \\
\hline Cleaner & 8 & 3 & \\
\hline \multicolumn{4}{|c|}{ ANNUAL HEALTH EXAMNATION } \\
\hline Yes & 7 & 3 & 1 \\
\hline No & 23 & 12 & \\
\hline
\end{tabular}

education, annual medical check-up and formal education are important factors that may drastically reduce the prevalence of food borne illness cases world-wide especially in developing countries like ours ${ }^{33}$. In the present study we have studied 45 food handlers from major hospitals in Solapur city, Maharashtra. Of which cook were 20 (44.44\%), servers $14(31.11 \%)$ and cleaners were $11(24.44 \%)$.

Among the food handlers 22 (49\%) were males while $23(51 \%)$ females. The age group of food handlers ranged from 18-75 years, none of the food handler was minor. Study done by Assefa et $\mathrm{al}^{29}$ showed females were more commonly involved in food handling as compared to males while the study done by Hasan et $\mathrm{a}^{14}$ and Allam et $\mathrm{al}^{19}$ showed results in contrast to our study. In the present study majority of the food handlers had at least primary school education. The age group among food handlers was widely between 18-75 years but none of the age groups showed a cluster of cases within bacterial contamination of hand and anterior nares of food handlers. In the present study annual health check-up among food handlers was done for 10 (22.22\%) individuals which is low. Study done by Nasrolahei et $\mathrm{a}^{30}$ showed results similar to our study. Study done by Assefa et $a^{29}$ showed all food handlers in their study had regular annual check-up.

However, in the present study, no statistical association $(p>0.05)$ was seen between hand contamination rate, age group, either sexes, 


\title{
BACTERIAL ISOLATES OF HAND \& ANTERIOR NARES
}

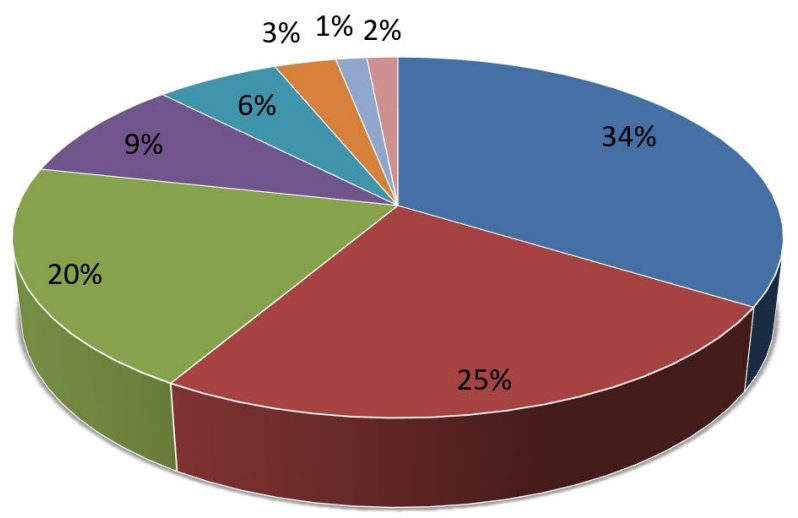

\author{
- Staphyloccocus aureus \\ Bacillus species \\ Diphtheroids \\ - Citrobacter species \\ CONS \\ Proteus species \\ E. coli \\ Enterococcus
}

Fig. 4. Cumulative data on bacterial isolates obtained from hand and anterior nares of food handlers

education status, economical condition, annual medical check-up, use of hair-accessories, use of finger ornaments and fingernail status is seen. It also does not show association between informal hand hygiene training or regular hand washing with hand contamination. This may be because even though $73.3 \%$ washed their hands regularly and also $73.3 \%$ had trimmed nails none of them used soap or any kind of sanitizer to clean their hands. Hand washing with warm water and liquid soap is recommended for $40-60$ seconds to reduce hand contamination ${ }^{34}$. This shows high level of negligence about hand washing among the food handlers and this led to the isolation of various bacterial isolates. Study done by Allam et al $^{19}$ shows results similar to our study, as food handlers lack standards of hand hygiene, however our study differs from their study as majority of food handlers in our study had their nails trimmed. In the present study overall most common organism isolated from hands and anterior nares of food handlers was Staphylococcus aureus $33.84 \%$ followed by Bacillus species $24.61 \%$, Diphtheroids 20\%, Citrobacter species $9.23 \%$, CONS 6.2\%, Proteus species $3.07 \%$, E.coli $1.53 \%$, Enterococcus species $1.53 \%$. Study done by Assefa et $\mathrm{al}^{29}$ and Nasrolahei ${ }^{30}$ showed Staphylococcus aureus as the predominant organism isolated from food handlers. However the percentage of Staphylococcus aureus in the present study is less than that in the study done by Mohtaram Nasrolahei ${ }^{30}$ probably because of the type of food establishment, difference in literacy and hand hygiene practices.

Allam et al $^{19}$ assessed the hand contamination of food handlers working in Menofia University and Shebin Al-Kom educational hospital in 2016. They assessed 72 food handlers by using a pre structured questionnaire, collecting data about the socio-demographic characteristics, personal hygiene practices and risk factors of contamination. A sterile polyethylene bag containing $100 \mathrm{ml}$ of peptone was used to collect hand rinse samples. This method is different from the one done by Mohanad Hasan Mohamed Honua $^{14}$ in Sudan in 2018 where the sterile swab method was used. However it is similar to the methodology used by Shojaei et al ${ }^{28}$ in Iran in 2005 and Assefa et al ${ }^{29}$

In the study done by Allam et $\mathrm{al}^{19} 70.8 \%$ of food handlers were male. This is because food handling in Egypt is mainly a men occupation. Majority of isolates were of $E$. coli $41.7 \%$ and of Staphylococcus aureus $29.2 \%$. The study showed being illiterate, ignoring hand washing after toilet and not trimming finger nails regularly are 
important sources that contribute to food borne illness.

Nasrolahei et al $^{30}$ assessed 220 food handlers in Sari city, Iran in 2016. In this study structured questionnaire was given asking about important parameters which included age, sex, literacy level, health education status, income and hand hygiene practices. In this study also males were more than females. The study showed highest prevalence of Staphylococcus aureus 46\%, followed by $E$. coli $29.2 \%$ which is in contrast to the study done by Allam et al ${ }^{19}$ The results are consistent with the study done by Assefa et $\mathrm{a}^{29}$ which also showed highest prevalence of Staphylococcus aureus $23.5 \%$ followed by $E$. coli $10.9 \%$. The study also isolated S. aureus $65 \%$ from the anterior nostrils of the food handlers. Highest prevalence of Staphylococcus aureus in the study done by Nasrolehei et $\mathrm{al}^{30}$ is because it is the true pathogenic bacteria included in the resident microflora of the skin and $40-50 \%$ of the healthy people carry Staphylococcus aureus in their anterior nares of the nose ${ }^{31}$. In this study highest rate of bacterial infestation was found among people with low income level. Hence it is estimated that better the living conditions lower the prevalence rates. In this study no significant difference in the rate of bacterial contamination was observed in between two genders.

The study done by Tsegaye Assefa and et $\mathrm{a}^{29}$ in 2015 however found no association between bacterial hand contamination and gender, educational background, medical checkups, training in hand washing, finger nail status, hand washing habits of food handlers. However it was found that a significant difference in the age groups with the younger age groups having higher bacterial contamination. It also showed significant association of bacterial contamination and cleanness of outer garments. There was also significant association between bacterial contamination and service experience. It showed that food handlers with more work experience had less risk of bacterial contamination. Source of gastroenteritis associated by Staphylococcus aureus toxins can be from nose or skin flora of carrier food handlers ${ }^{37}$. Lack of hand hygiene practices by food handlers can easily lead to contamination of food thus resulting in food borne illness among people consuming such food items ${ }^{36,37}$.

Presence of organisms like Bacillus species in the hands of food handlers may be due to contact with contaminated raw products like vegetables, unwashed fruits, poultry ${ }^{38}$.

Isolation of Diphtheroids, CONS and other enteric pathogens like Citrobacter, E. coli can be easily removed by washing hands with soap and water as these are transient flora acquired during course of their work. Isolation of such organisms in the present study shows potential of fecooral transmission of pathogens indicating that compliance of hand hygiene practices is lacking among food handlers ${ }^{39}$.

Hence it is most important that there should be regular check-up and lectures to sensitize food handlers on importance of hand washing to prevent spread of food borne illness among healthy individuals. Infected employees should be immediately relieved from their duties for proper treatment and should be excluded completely from handling of food items in any way. Till the time, they are appropriately treated. There is a need for proper screening procedure which will be helpful to diagnose food handlers who are carrier or infected and treat them and thus lead to decrease in morbidity among people having food from these outlets.

WHO recommends hand washing for 2030 seconds if hand is not visibly soiled and 40-60 seconds if visibly soiled. It also recommends the use of alcohol based sanitizer and antibacterial soap respectively. The food handlers need to be educated about this to improve their personal hygiene.

\section{CONCLUSION}

Food handlers may act as important source for food borne illness. It is important to sensitize persons involved in food handling about hand hygiene, self-hygiene practices, as due to lack of this knowledge these people tend to contaminate food and thus results in food borne illness, which poses as public health problem of global concern. It is essential that higher authorities should arrange awareness programs for these people about hand hygiene, and importance of hygiene in food handling. The 
authorities should make a provision of annual medical check-up and immunization of these food handlers to prevent outbreaks of food borne illness. Lack of proper food handling practices has been attributed as a leading cause of majority of food borne diseases.

\section{Recommendation}

- All food handlers should be taught the right technique of hand hygiene.

- Routine checkups should be conducted on all food handlers at least annually. Appropriate treatment should be administered to those who are found to be infected.

- Infected food handlers should not be allowed to perform any work that includes touching the food directly or indirectly example washing utensils, etc.

- Provide proper wash basins and alcohol containing soaps do that the food handlers can wash their hands.

- Food handlers should be encouraged to use alcohol based sanitizer or antibacterial soap to wash their hands.

\section{ACKNOWLEDGMENTS}

None.

\section{CONFLICT OF INTEREST}

The authors declare that there is no conflict of interest.

\section{AUTHORS' CONTRIBUTION}

All author's listed have made a substantial direct and intellectual contribution to the work and approved it for publication.

\section{FUNDING}

This project was funded by Indian Medical Council of India (ICMR) under short term studentship (STS) (Grant Ref no- 2019.03601).

\section{DATA AVAILABILITY}

All the data set generated or analyzed during this study are included in the manuscript.

\section{ETHICS STATEMENT}

The study was approved by the institutional ethics committee (IEC) Dr. Vaishampayan Memorial Government Medical College ,Solapur, Maharashtra-413524 . Permission from other hospitals to conduct study on their food handlers was also taken. Written consent was taken from all the participants included in the study.

\section{REFERENCES}

1. WHO. World Health Organization global strategy for food safety: safer food for better health. 2004.

2. WHO. www.who.int>health-topics

3. Vemula SR, Kumar RN, Polasa K. Foodborne diseases in India- a review. British Food Journal. 2012;114:661680.

4. Kaferstein FK. Food safety the fourth pillar in the strategy to prevent infant diarrhea. Bulletein of World Health Organization. 2003;81:842-843.

5. Nasrolahei M, Mirshafiee S, Khaldi S, Salehian M. Nasrolahei M. Bacterial assessement of food handlers in Sari city, Mazandaran Province, north of Iran. Journal of Infection and Public health. 2017;10:171-176. doi: 10.1016/j.jiph.2016.03.006

6. Fendler EJ, Dolan MH, Williams RA. Hand washing and glowing for food protection. Part 1 Examination of the Evidence Dairy Food Environ Sanit. 1998;18:814-823.

7. Audit commission. Environment Health survey of Food premises. HMSO, London. 1990.

8. Takalkar AA, Kumavat AP. Assessment of personal hygiene of canteen of workers of government medical college and hospital, Solapur. National Journal of Community Medicine. 2011; 2(3):448-451.

9. Michaels $B$, Keller $C$, Belvins $M$, et al. prevention of food worker transmission of foodborne pathogen: risk assessment and evaluation of effective hygiene intervention strategies. Food Service Technology. 2004;4:31-49. doi: 10.1111/j.1471-5740.2004.00088.x

10. Centers for Disease Control and Prevention. www.cdc. gov >foodsafety

11. Pickering AJ, Boehm AB, Mwanjali M, Davis J. Efficacy of Waterless Hand Hygiene Compared with Handwashing with Soap: A Field Study in Dar es Salaam, Tanzania. Am J Med Hyg. 2010;82:270-278. doi: 10.4269/ ajtmh.2010.09-0220

12. Snyder O.P. A "safe hands" Hand wash program for retail food operations. A technical review. Environ. Microbiol. 2004 ;43: 1219-1220.

13. Your Guide to the Consumer Price Index. Minister of Industry, Canada 1996. Catalogue No. 62-557-XPB.

14. Honua MHM. The bacterial contamination of food handlers hand in Wad madani city restaurants, Sudan. International Jornal of Community Medicine and Public Health. 2018;5(4):1270-1273. doi: 10.18203/23946040.ijcmph20181201

15. Leus JFR, Tonder IV. The occurrence of the bacteria on hands and aprons of food handlers in the delicatessen sections of the retail group. Food Control. 2007;18:326332. doi: 10.1016/j.foodcont.2005.10.010

16. Bassyouni RH, El-Serbiny N, HEfzy EH, Wegdan AA. Perception of food safety and prevalence of Staphylococcus aureus and salmonella species carriers among Fayoum University food handlers. Life Science Journal. 2012;9(4):2934-2940.

17. Allwood PB, Jenkins T, Paulus C, Johnson L, Hedberg 
CW. Hand washing compliance among retail food establishment workers of Minnesota. Journal of Food Protection. 2004;67(12):2825-2828. doi: 10.4315/0362-028X-67.12.2825

18. Guzewich J, Ross MP. Evaluation risks of microbiological Contamination of ready to eat food by food preparation workers and the effectiveness of interventions to minimize those risks. Food and Drug administration Center for food safety and applied nutrition. 1999.

19. Allam HK, Al-Batanony MA, Seif AS, Awad ET. Hand contamination among food handlers. BMJ. 2016;13(5):1-8. doi: 10.9734/BMRJ/2016/24845

20. Fendler EJ, Dolan MJ, Williams RA. Hand washing and gloving protection: part I. Examination of evidence. Dairy Food Environ Sanit. 1998;18:814-823. doi: 10.1108/00070701211229954

21. Shinkawa N, Noda M, Yoshizumi S, et al. Molecular epidemiology of noro viruses detected in food handler associated outbreaks of gastroenteritis in Japan. Intervirology. 2008;51(6)422-426. doi: $10.1159 / 000205527$

22. Stein-Zamir C, Tallen-Gozani E, Abramson N, et al. Salmonella enteric outbreak in a banqueting hall in Jerusalem; the unseen hand of the epidemiological triangle. Israel Med Assoc J. 2008;11:94-97.

23. WHO- Prevention and control of intestinal parasitic infections. World Health Organization, Geneva 1987:718. (Technical report series no. 749).

24. Bas M, Erun AS, Kivanc G. The evaluation of food hygiene knowledge, attitude and practices of food handlers in food business in Turkey. Food Control. 2006;17(4): 317-322. doi: 10.1016/j.foodcont.2004.11.006

25. Codex Alimentarius. Recommended International code of practice general principles of food hygiene. CAC/ RCP. 2003;1-1969, Rev 4.

26. Harrison WA, Griffith CJ, Ayers T, Michaels B. Bacterial transfer and and cross-contamination potential associated with paper- towel dispensing. Am J Infection Control. 2003;31(7):387-391. doi: 10.1067/ mic.2003.81

27. Shojaei H, Shooshtraipoor J, Amiri M. Efficacy of simple hand washing in reduction of microbial hand contamination of Iranian food handlers. Food research International. 2006;39(5):525-529. doi: 10.1016/j. foodres.2005.10.007

28. Assefa T, Tasew H, Wondafrash B, Beker J. Assessment of bacterial Hand contamination and associated factors among food handlers working in student cafeterias of Jimma University Main Campus, Jimma, South West Ethiopia. Community Medicine and Health Education. 2015;5:345. doi: 10.4172/2161-0711.1000345

29. Brodie J. Hand Hygiene. Scottish Medical Journal. 1965;10(3):115-125. doi: 10.1177/00369330 6501000304

30. Koneman EW. Koneman's color atlas and textbook of diagnostic microbiology:Lippincott Williams \& Wilkins. 2006.

31. Gudeta D. Sanitary Survey of Food and Drinking Establishments in Ambo Town West Showa zone Oromia Region. Addis Ababa University. 2007.

32. Bennet JV, Holmberg SD, Rogers MF, Solomon SL. Infectious and parasitic diseases. In: Amler RW, Dull HB eds. Closing the gap: the burden of unnecessary illness. New York: Oxford university Press 1987:102-114.

33. Fadel HM, Ismail J. Prevalence and significance of Staphylococcus aureus and Enterobacteriaceae species iin Selected Dairy Products and handlers. International Journal of Dairy Science. 2009; 4(3):100-108. doi: 10.3923/ijds.2009.100.108

34. Brooks GF, Butel JS, Morse SA. Medical microbiology 21st edition. New York: Lange Medical Books/ Mc Graw Hill Medical Publishing Division. 1998:466.

35. Isara AR, Isah EC, Lofor PVO, Ojide CK. Food contamination in fast food restaurants in Benin city, Edo state, Nigeria. Implication for food hygiene and safety. Public Health. 2010;124(8):467-471. doi: 10.1016/j.puhe.2010.03.028

36. Larson E, McGinley KJ, Grove GL, Leyden JJ, Talbot $\mathrm{GH}$. Physiologic, microbiologic and seasonal effects of hand washing on the skin health care personnel. Am J Ifect Control. 1986;14(2):51-59. doi: 10.1016/01966553(86)90055-6

37. Souza PA, Santos DA. Microbiological risk factors associated with food handlers in elementary schools from brazil. Journal of Food Safety. 2009;29:424-429.

38. World Health Organization. Hand Hygiene: Why, How \& When? 2019:1-3.

39. Clayton DA, Griffith DJ, Price P, peters AC. Food handlers beliefs and self- reported practices. Int J Eviron Health Res. 2002;12(1):25-39. doi: 10.1080/09603120120110031 